Article

\title{
The Mimetic Faculty and the Art of Everyday Life ${ }^{1}$
}

\section{Milan Kroulík}

\begin{abstract}
In this paper I attempt to rethink the relationship between art and life by formulating it based on the rereading of the Benjaminian mimetic faculty by the anthropologist Michael Taussig. Taking this position within history as non-teleological change and based on human activity, to uphold a distinction between original and representation metaphysically becomes impossible. This is important in so far as any notion of primacy becomes obsolete, while at the same time one can work with the historical existence, both material and ideational, of initially abstract concepts such as art. Art then is something that in itself does not have a materially specific reality, but forms reality through artworks, institutions, pecuniary allocations or human motivation. Taking art as a world-forming force that is nonetheless historically produced in turn opens up new, pluralist ways of using this historical given for possible futures.
\end{abstract}

Keywords: Taussig, Marxism, mimesis, aesthetics

The following pages would not have been possible for me to write without the experience of taking and arranging images, be it as photography or as films. Such experience however is only half present: there and not there. Without it, I could not have created this text, and image-making practices helped me generate and organize thoughts, even if I do not specifically treat the topic. Cinema haunts this writing, for cinema, today, is part of the fabric of life.

I.

W here is art said to come from? For some influential figures, an artwork was the copy of a copy of an idea, and thus inferior. The practices and resulting products today regarded as art could be

${ }^{1}$ This essay was written within the project Crisis of Rationality and Modern Thought, within the grant project Cinema as the Exteriority of Rationality, at the Charles University, Faculty of the Arts, with financial support of the Specific university research in 2018.

(c) 2019 Milan Kroulík

https://www.kritike.org/journal/issue 24/kroulik june2019.pdf

ISSN 1908-7330

(cc) BY-NC-ND 
subsumed as one coherent group. But there was no art as such. ${ }^{2}$ As the Western idealist narration of history tells it, there came a time when this image of the world was inverted. Reality was no longer a mere imitation of eternal ideas; it was thought as the origin. Unfortunately, art is still considered a copy of reality. And it just is, much like the works that are considered to be its manifestations that are mere imitations of something apparently, if inexplicably better. And with all these imitations there was apparently nobody (that is, nobody would have made it into the unified, canonical narrative of History) who would have asked the questions: "How did anybody manage to produce that copy of reality? How did anybody manage to apprehend that one is the copy of the other?" That which is necessary for idealist philosophy and modern/capitalist cosmology to work in the first place, is generally erased. As Marx in his typically biting style puts it: "Even when the sensuous world is reduced to a minimum, to a stick as with Saint Bruno [Bauer], it presupposes the action of producing the stick." 3 For there to be a stick, it must first become a stick. To rephrase this in the more contemporary language of deconstruction, praxis-here, material production-is a Derridean "dangerous supplement" 4 to thought, or ideational production. The officially erased activity that makes a thing a thing is a necessary condition and if said thing were to become again, it cannot do without practical activity.

One of the most interesting ways to unearth what has been covered by centuries of burying by bourgeois intellectual praxis, has been formulated by Walter Benjamin and Theodor Adorno. This line of conceptual work is being elaborated, idiosyncratically, for the post-colonial age(s), by the writings of the anthropologist Michael Taussig. The issue is the following: "If there is a copy (representation) and the original (reality being represented), there must be somebody copying (representing). In what relation then do these three phenomena stand?" This possibility is already inherent in Marx, for it is with his work that the question of production emerges. Nevertheless, there seem to have been few Marxisms and Marxists that have approached Marx's work as that of an anthropologist, that is, as someone concerned with what different humans do and how humans come to be, from the point of view of the human and not some abstract transcendental. It is not a question of what a human is. Benjamin's proposition for this problem is the concept of

2 Stephen Halliwell, The Aesthetics of Mimesis: Ancient Texts and Modern Problems, (Princeton: Princeton University Press, 2002), 7.

${ }^{3}$ Karl Marx and Friedrich Engels, "Opposition of the Materialist and Idealist Outlooks," in Karl Marx and Friedrich Engels, The German Ideology including Theses on Feuerbach and Introduction to the Critique of Political Economy, trans. by C. Dutt, W. Lough, and C.P. Magill (New York: Prometheus Books, 1998), 47.

${ }^{4}$ Jacques Derrida, “... That Dangerous Supplement ...," in Of Grammatology, trans. by G.C. Spivak (Maryland: The Johns Hopkins University Press, 1976).

(C) 2019 Milan Kroulík

https://www.kritike.org/journal/issue 24/kroulik june2019.pdf

ISSN 1908-7330 
the "mimetic faculty," ${ }^{5}$ which is at the crossroads of nature and culture. ${ }^{6} \mathrm{He}$ writes:

Nature produces similarities. One need only think of mimicry. The highest capacity for producing similarities, however, is man's. His gift for seeing similarity nothing but a rudiment of the powerful compulsion in former times to become similar and behave mimetically. There is perhaps not a single one of his higher functions in which his mimetic faculty does not play a decisive role. ${ }^{7}$

Every time I reread this short essay, I experience again the shock to the foundations of idealist cosmology that I experienced the first time I read it. ${ }^{8}$ Or so I tell myself. Like Benjamin, Michael Taussig thinks that "... the mimetic faculty is the nature that culture uses to create second nature, the faculty to copy, imitate, make models, explore differences, yield into and become Other. The wonder of mimesis lies in the copy drawing on the character and power of the original, to the point whereby the representation may even assume that character and that power." ${ }^{9}$ Copies are as powerful as the original. How is this possible? There is a "two-layered notion of mimesis that is involved -a copying or imitation, and a palpable, sensuous, connection between the very body of the perceiver and the perceived." 10 There is no imitation without

\footnotetext{
${ }^{5}$ In German, Walter Benjamin uses the word "Vermögen," which can be translated as "ability," "capacity," as well as "faculty." Here, I follow the standard translation, which apart from being conventionalized, nicely stresses the intimate relationship with the mind or body.

${ }^{6}$ This question of the interaction of nature and culture arises in Marx. E.g., "They themselves begin to distinguish themselves from animals as soon as they begin to produce their means of subsistence, a step which is conditioned by their physical organisation." Marx and Engels, "Opposition," in The German Ideology, 37.

7 Walter Benjamin, "On the Mimetic Faculty," trans. by Edmund Jephcott, in Selected Writings: Volume 2, Part 2, 1931-1934, ed. by Michael W. Jennings, Howard Eiland, and Gary Smith (Cambridge, MA and London England: The Belknap Press of Harvard University Press), 720 .

8 Throughout the text, I use idealist cosmology as a polemical shorthand for a world where material things are in one way or another seen as depending on their immaterial, ideational counterparts. The former generally standing on the weaker side of this relation. This leads to a certainty about what any thing already is, and makes it hard to perceive how any such thing exceeds the image one already has of it, even if, quite evidently, practical engagement doesn't necessarily follow ways of thinking. I do not want to claim that this has been the only way within Western thought, otherwise I obviously wouldn't be writing what I am, nor within Western historical cosmologies, of which I know too little to assert any clear position. Nevertheless, from my experience it is a dominant way of dealing with reality, even with many Marxists.

${ }^{9}$ Michael Taussig, Mimesis and Alterity: A Particular History of the Senses (New York: Routledge, 1993), xiii.

${ }^{10}$ Ibid., 21.

(c) 2019 Milan Kroulík

https://www.kritike.org/journal/issue 24/kroulik june2019.pdf

ISSN 1908-7330
}

(c) BY-NC-ND 
contact, and no contact without imitation. Furthermore, as "a faculty, it is also a history, and just as histories enter into the functioning of the mimetic faculty, so the mimetic faculty enters into those histories." 11 Benjamin's formulations, too, are a history. The aim of this work is to think the relationship between art and life from within this history, and what it entails for the production of artworks.

\section{II.}

In Aristotle's Poetics one can read the following passages: “... the instinct of imitation is implanted in man from childhood, one difference between him and other animals being that he is the most imitative of living creatures, and through imitation learns his earliest lessons; and no less universal is the pleasure felt in things imitated. We have evidence of this in the facts of experience" 12 or "tragedy is an imitation, not of men, but of an action and of life, and life consists in action, and its end is a mode of action, not a quality." 13 According to Lacoue-Labarthe, it is about "the recognition of the same and the similar."14 But what can also be recognized is that, for Aristotle, the same and the similar are not produced by the same process. Thus, it comes as little surprise that the rest of his work falls back into what appears to me to be arbitrary metaphysical assertions and does not further think about where sentient beings make use of this 'instinct of nature' he calls imitation. Neither does most of Western intellectual history. The mimetic faculty is being written out of History and History does not bear on it. Yet, history is not History. It is change. It is productive. It is made, just like artworks. And like the latter, the making of history takes place at the crossroads between culture and nature.

So, here we are. Culture uses nature to create second nature. One tries to stand at the crossroads. It is given and made at the same time. Reality as constructed and not-constructed, "as really made-up." 15 Life imitates art and art imitates life. Life shapes art and art shapes life. And sentient beings are caught within the maelstrom of imitation, with the ground for unambiguous identity disassembled, yet continuously reassembling. Just like in montage, the sense of images changes depending on preceding and following images, subjective (personal) and objective (interpersonal). "Pulling you this way and that, mimesis plays this trick of dancing between the very same and the very different. An impossible but necessary, indeed an

\footnotetext{
${ }^{11}$ Ibid., xiv.

${ }^{12}$ Aristotle, Poetics, trans. by S. H. Butcher (London: MacMillan \& Co., 1902), IV.

${ }^{13}$ Ibid., VI.

${ }^{14}$ Phillipe Lacoue-Labarthe, Poétique de l'histoire (Paris: Galilée, 2002), 85-86.

${ }^{15}$ Taussig, Mimesis, 251.
} 
everyday affair, mimesis registers both sameness and difference of being like, and of being Other." 16 Any grounds for a radical separation between art and reality, between nature and culture, between history and being(s) collapse. But where does this leave our dominant idealist cosmology, whose classificatory system makes an essential categorical distinction between art and life? If history (or rather histories) and beings are productive, so must idealism be. So must the concept of art be. How then are we to rethink art on the basis of the mimetic faculty?

\section{III.}

It is written in the idealist canons of Western modernity that there are two ways of thinking about art. One is commonly said to be conceived on the grounds formulated by Kant. The other, perhaps less acknowledged, on the grounds formulated by Rousseau. As the stories go, the first is one of "disinterested" reflection from within the world, while the other can be characterized by "interested" effectuation of specific changes on the world. As such, the first appears as conceptualized from within a situation of art appreciation, and the second, from within the situation of art creation. The first wants to overcome the negatively perceived (sensual) effects of art on the sentient being in a situation of encounter with an artwork in favor of (hopefully) purely intellectual perceptive pleasure; ${ }^{17}$ the other wants to maximize the (presumably intellectual) effects of an artwork on society..$^{18}$ Both forget about the necessary mediation by the material. ${ }^{19}$ In a sense, both approaches see double: there is and is not an effect of art on the individual in society - and this effect (negative or positive) is imagined as total, as unified. Each approach wants to minimize the influence of one pole over the other, which is in and of itself hardly problematic. The problem arises when these two poles are treated as radically separate instead of two aspects that are always present. This happens because both the actively mediating materiality and the actively participating subject are erased and forgotten. Paradoxically, the basis for the cognitive creation of total difference is thinking based on primary identity-between objects, their material and cognitive representations, and often those that do the representing.

\footnotetext{
16 Ibid., 129.

${ }^{17}$ Some writers complicated this simplified reception of Kant, e.g. Halliwell, Aesthetics, $9 \mathrm{ff}$.

${ }^{18}$ How often is it that the basic referent for change is one concrete, historical subject and not either an abstract, totalized society or a transcendental, ahistorical subject?

${ }^{19}$ Cf. Sybille Krämer and Horst Bredekamp, “Kultur, Technik, Kulturtechnik - Wider die Diskursivierung der Kultur," in Bild, Schrift, Zahl, ed. by Sybille Krämer and Horst Bredekamp (München: Wilhelm Fink Verlag, 2009), 11-23.
}

(c) 2019 Milan Kroulík

https://www.kritike.org/journal/issue_24/kroulik june2019.pdf

ISSN 1908-7330

(c) BY-NC-ND 
Negative dialectics is one of the methods out of this idealism: "Crucial to 'negative dialectics' was not only the object's nonidentity with itself, but its nonidentity with the knowing subject, the mind and its logical processes." 20 Identity-thought conflates all the little differences, the uncertainties, the pluralities that can, at times, be difficult to perceive ${ }^{21}$ and transforms continua of transformations into one or two static blocks, depending on the cosmological configuration. But art and life are histories, and thus, change. This is why they are separate, despite the fact that they draw on each other. They are similar and different at the same time. Then, there is the third: the artist. The human is subject-object living in a society with a classificatory model that produces the figure of the artist. The person imitates this figure and the figure imitates the people. The person is considered an artist and considers herself an artist. The creation of a category is one of interaction by societal and individual formation; it is historical. It is history, but it is not history. It is nature, but is not nature. It changes nature, it becomes nature. Also, the category is productive. It produces the artist. It makes history. The artist, too, makes history. ${ }^{22}$ But an artist is not another artist. Neither is she art. Neither the category. They come from each other, they are imitating each other, but they imitate many forms, material and immaterial. They are neither different nor identical; they are both, they are similar. So, what came first: art (category), the artist (producer), or the artwork (material)? Neither, of course. They all make each other.

\section{IV.}

Imagine two scenes: one, of artwork production, and the other, of artsense production. Let us say we have a painter. There she is, in front of the painting to become. Brush in hand, atelier around her, empty canvas in front of her. All things here have become histories. They have been produced by other makers transforming nature into culture, creating objects that are always already both. How does such a technological object come about? It is not found in nature. What must be done is to make all that was learned into

\footnotetext{
${ }^{20}$ Susan Buck-Morss, The Origin of Negative Dialectics: Theodor W. Adorno, Walter Benjamin and the Frankfurt Institute, (London and New York: Collier Macmillan, 1977), 77. See also Theodor Adorno, Negative Dialectics, trans. by E.B. Ashton (London and New York: Routledge, 1973).

${ }^{21}$ Benjamin is radical precisely because he begins his thought processes with such minutiae and does not try to "put them on the procrustean bed of reason." Buck-Morss, Origin, 107.

22 "The materialist doctrine concerning the changing of circumstances and upbringing forgets that circumstances are changed by men and that the educator must himself be educated." Karl Marx, Theses on Feuerbach, in Marx and Engels, The German Ideology including Theses on Feuerbach and Introduction to the Critique of Political Economy, 569-570 (Thesis III).
}

(C) 2019 Milan Kroulík

https://www.kritike.org/journal/issue 24/kroulik june2019.pdf

ISSN 1908-7330 
an object. A specific combination of transformations of both ideational and material forms. The brush itself then becomes history, for it has the ability to make history, to form reality, to co-produce further imitations. But now, the labor is on our painter and her materials. And the aim is to bring a whitish canvas, that is a canvas already filled with structure and color, to a state where some putative other can say: "Now, this is a painting!" In order to arrive at the categorization of an object as a painting, that is to make sense of a specific material object, one must also work. One must make use of the mimetic faculty to discern similarities and differences. Just try to remember all the effort that went into acquiring the ability to enjoy art, to learn to distinguish between what is art and what is not, to learn to stand still in a museum. Not to mention all the work done by those making it possible for the places within which one views art to come into being and continue being. Neither art-production nor art-consumption is a given, both are productions in constant becoming produced/producing.

What (historically specific) tool-kit can the artist-person draw from? The list, I imagine, could go something like this: art as efficacious category, available materials (always already modified) and technical apparati, bodily techniques and sensual perceptions, cultural imaginary, funds. ${ }^{23}$ All of these phenomena enable the emergence of the scene proposed above. And indeed, my writing and your reading too. ${ }^{24}$ And neither the artist, nor her ability to create an artwork is self-identical; each is a variation of what became before. ${ }^{25}$ Learning which forms can serve to establish similarities and which cannot, that is, learning to use the mimetic faculty, is historical. Artist, like all others, must learn by copying the available tool-kit, based on which works can be produced. Different trades are different histories, and make possible different correspondences. A painter will have different bodily techniques (copied

23 'Art' is what makes the scene possible in the first place. By materials and technical apparati, I mean things like brushes, types of paint, pigment, etc. By bodily techniques I mean gestures, poses, angles, perceptions, etc. By sensual perceptions, types of brush strokes, angles, etc.

Cultural imaginary, I take to mean that which has been represented, what can be represented - the intertwined histories of art and nature that are present in a society at a given moment. Even in one society there will exist different form-histories and thematic histories that enable and legitimize differing variations. Whatever the currently available wealth of forms, they are accessible through the mimetic faculty-the ability to perceive and produce similarities within difference. Difference and similarity are the products of the same processes.

And with funding I also mean exchange value, that is the allocation (itself possible through abstraction) of money that creates and structures the possibilities of the creation of art.

24 "... the notion that writers and artists were themselves productive workers, more similar to the proletariat than to their capitalist exploiters, was widespread among members of the Berlin circle. Brecht referred to intellectuals as 'brain-workers' (Kopfarbeiter) and Benjamin wrote a theoretical article on 'The Author as Producer."' Buck-Morss, Origin, 32.

${ }^{25}$ See also Buck-Morss, Origin, $44 \mathrm{ff}$.

(c) 2019 Milan Kroulík

https://www.kritike.org/journal/issue 24/kroulik june2019.pdf

ISSN 1908-7330

(cc) BY-NC-ND 
from others) than a baker. And while each will have their bodies and minds formed for their profession, either can, in fact, learn (copy) what the other is doing, should they consciously make use of their abilities to see similarities in the production process, and not merely in the resulting artwork, which is caught in a differing web of correspondences. Imitating techniques from other, seemingly unrelated, professions might even lead to radical innovation. Life and art are intertwined not merely because they are both variations on forms, but because they are the fruits of practical activity and themselves engender further practical activity. Seeming chasms between humans appear when people are only aware of similarities between objects and ideational forms of objects. That is, objects are seen from the point of view of ideas. It is granting products of labor (cultural and natural) and thus, History primacy qua objects, while making all efforts not only to hide objecthistories, but also object-history-making.

In more ancient times, according to Benjamin, it was a compulsion to behave and become like something else. That is also what European travelers repeatedly encountered: humans that are extremely adept at imitating. But it becomes apparent that who imitated whom in such encounters was not at all clear. ${ }^{26}$ Moderns, just as their imagined European forebears, never completely unlearned the conscious use of the mimetic faculty. ${ }^{27}$ Mimesis is still basic to other functions. We yield to objects and to beings, at times consciously, at other times not so much. And we do this while participating in artworks as creators and as consumers.

\section{V.}

You, reader, might opine that art appreciation is also about feelings, about pleasure, ${ }^{28}$ not just about production, about work, about tools, practical or conceptual. And you are right. Life is also about pleasure and other emotions. Yet, even emotions are produced from within certain constellations that are not, cannot be, exclusive to art. Art may produce contexts of intensified emotion or of specialized emotion, but who is to say that life is not intense? Even more, how could art be appreciated-intellectually, formally, emotionally - without everyday experiences? Thus, not only everyday bodily techniques are part of artistic techniques, but emotional experiences, too. Thus, in official Western intellectual history, there have, again and again,

\footnotetext{
${ }^{26}$ Taussig, Mimesis, $73 \mathrm{ff}$.

${ }^{27}$ This was what Benjamin learned by studying children. See e.g., Susan Buck-Morss, The Dialectics of Seeing: Walter Benjamin and the Arcades Project (Cambridge, MA: MIT Press, 1989), 267-268.

IV.

28 "... and no less universal is the pleasure felt in things imitated." Aristotle, Poetics,
}

(C) 2019 Milan Kroulík

https://www.kritike.org/journal/issue 24/kroulik june2019.pdf

ISSN 1908-7330 


\section{THE MIMETIC FACULTY}

surfaced views that intensified emotions lead to numbing. ${ }^{29}$ Or, on the contrary, that intensified emotions will somehow lead to an imitation of what is represented, in seeking to experience the same emotions. Both rest on the metaphysical assumption that representation is, in one way or other, not "real," which poses the body, our body (which seems to be always both our concrete body and the abstract, universal body) as more directly present than representation. ${ }^{30}$ Hence, emotions produced by representation are somehow worse than those produced by reality. The underlying issue is one of how our material, acting bodies, and such bodies of others appear, that is, come to represent themselves, in our consciousness. ${ }^{31}$ And how these bodies are mediated by our different senses. But, from our understanding, senses are historical: "Just as the entire mode of existence of human collectives changes over long historical periods, so too does their mode of perception. The way in which human perception is organized-the medium in which it occurs-is conditioned not only by nature but by history." 32 Material culture is both natural and cultural, and subject to change. It, in turn, produces different sensual (perceptive) existence. Furthermore, different material encounters produce different sensorial-affective effects. And emotions, feelings appear with encounters, as mediated by historical senses. Different material media do not produce separate effects, for they are never "pure" in relation to their specific sense-mediation. ${ }^{33}$

${ }^{29}$ Rousseau, in his 'Letter to d'Alembert', is a prime example of idealist cosmology. Perhaps, because he sincerely tries to think his position through, many contradictions become glaringly apparent: On the one hand, he holds that art (here theatrical representation) has an effect on people, on the other he claims that cultures (for him: totally separate, totally totalizing in relation to humans and ahistorical, yet historical entities) have their own specific tastes and contingent representations, that do not speak to other cultures. But how can they not speak to others, if they have an effect? See Jean-Jacques Rousseau, Politics and the Arts: Letter to M. d'Alembert on the Theatre, trans. by A. Bloom (Ithaca: Cornell University Press, 1960). See also Lacoue-Labarthe, Histoire, 95-100.

${ }^{30}$ The depths to which Western cosmology is historically contingent appears when the thought and practice of 'others' (both within and without the imagined category of the West) is taken seriously and not just as empirical evidence for European theory. Great work has been done by e.g., Alan Klima, "The Telegraphic Abject - Buddhist Meditation and the Redemption of Mechanical Reproduction," Comparative Studies in Society and History, $43: 3$ (2001), 552-582; 552$554,558$.

31 As Lacoue-Labarthe writes: "Rien n'est présent qui ne soit de quelque manière (re)présenté : en représentation." Lacoue-Labarthe, Histoire, 135.

32 Walter Benjamin, "The Work of Art in the Age of Its Technological Reproducibility,” trans. by Edmund Jephcott, in Selected Writings: Volume 3, 19351938, ed. by Howard Eiland and Michael Jennings (Cambridge, MA and London, Englad), 104.

(2005), 257-266.

${ }^{33}$ Cf. W. J. T. Mitchell, "There Are No Visual Media," Journal of Visual Culture, 4:2

(c) 2019 Milan Kroulík

https://www.kritike.org/journal/issue 24/kroulik june2019.pdf

ISSN 1908-7330

(c) $\mathrm{BY}-\mathrm{NC}-\mathrm{ND}$ 
Michael Taussig, in describing his experiences participating in rituals in the Upper Amazon, is instructive: "Furthermore, the senses cross over and translate into each other. You feel redness. You see music. Thus, nonvisual imagery may evoke visual means." ${ }^{34}$ Life and experience, existence, are produced by many influences, none of which are separable. This is not about conflation, but about creating new combinations. A painting viewed on Google produces a different effect than one viewed in a gallery. Viewed from the material ground up, they are different, but equal. One ought to not conflate them, but neither should one discard the other as inferior. After all, what good does it do (except for affirming an ideological hierarchy) since nowadays the majority encounters a painting in a copy first? Experience and emotions are non-identical to themselves; it is the secondary application of a concept that is made to act so as to subsume very real differences.

\section{VI.}

But neither are emotions and experience identical among each other. How then are we to relate emotions and mimesis? Emotions overwhelm us, they move us, they take us outside ourselves. ${ }^{35}$ They are passions. ${ }^{36}$ Idealist cosmology puts the sources of emotions and passions within humans, it is psychological-despite the fact that emotions arise in externally produced situations. How then are we to think emotions or feelings in a non-idealist way? Benjamin is instructive here. He imagines a source of feelings that is not located in the head. As cited by Michael Taussig:

... that we sentiently experience: a window, a cloud, a tree not in our brains but, rather, in the place where we see it, then we are, in looking at our beloved, too, outside ourselves. But in a moment of tension and ravishment. Our feeling, dazzled, flutters like a flock of birds in the woman's radiance. And as birds seek refuge in the leafy recesses of a tree, feelings escape into the shaded wrinkles, the awkward movements and inconspicuous blemishes of the body we love, where they can lie low in safety. And no passer-by would guess that it is just here,

34 Taussig, Mimesis, 57.

${ }^{35}$ Cf. Fritz W. Kramer, The Red Fez: Art and Spirit Possession in Africa, trans. by M. Green, (London/New York: Verso, 1993), 57-64.

${ }^{36}$ Kramer shows the closeness between passions and possessions: "These would normally be called not passiones, but rather possession, being moved or being filled with emotion." Kramer, The Red Fez, 60.

(C) 2019 Milan Kroulík

https://www.kritike.org/journal/issue 24/kroulik june2019.pdf

ISSN 1908-7330

(cc) BY-NC-ND 


\section{THE MIMETIC FACULTY}

in what is defective and censurable, that the fleeting darts of adoration nestle. ${ }^{37}$

Feeling and sentience take us outside ourselves. They are two sides of the same process and do not emerge solely from the dark recesses of souls. Many non-idealist, polytheistic cosmologies thus have immaterial entities that exist alongside material ones, and interact to produce emotions, possessions even. ${ }^{38}$ The human being is decentered, the interior and the exterior are not hierarchized. To be taken outside oneself still implies that there is a self as history. Mimesis obliterates Self, not self. Each encounter (let us act as if they were analytically separable) is specific, because with each being-takenoutside-oneself, the self changes. And returns similar, but different. ${ }^{39}$ This happens regardless of the physical context. Contexts co-produce differently; they enact differing possibilities for change. And within them, emotions and sensual experience are separate, but inseparable. And only retrospectively determinate.

\section{VII.}

Returning to the issue of the category "art", it feels necessary to ask: "Where then, does art come from?" Art is a product of specific circumstances and is itself a (co-)producer of further circumstances. ${ }^{40}$ But art is an abstract category, a form of classification, and as such, secondary as seen from materialist practice. It does not exist without humans. What is actually, physically produced is a thing that exhibits attributes which can be classified as an artwork, i.e. on which the category of art can be projected. But things have lives of their own. Things, even commodities, are like us-at the crossroads of nature and culture. And they are productive. ${ }^{41}$ They, too, take us outside ourselves. They make pleasure possible. This is surprising to some, since humans in capitalist societies dissimulate. We act as if objects were dead, passive, all the while defining ourselves by things, objectifying and fetishizing them, but unconsciously. At once above and below objects. Neither subjects nor objects. It is important "to awaken congealed life in petrified objects. Thus, Benjamin, in addressing the fetish character of

37 Taussig, Mimesis, 38.

${ }^{38}$ Cf. Kramer, The Red Fez, 6 and Taussig, Mimesis, 100 ff.

${ }^{39}$ Cf. Taussig, Mimesis, 246.

40 "These phenomena were doubly determined by history, both in the moment of their conception by the artist out of the material in its historically developed form, and in their existence after creation, when they acquired a life of their own." Buck-Morss, Origin, 52.

41 "The commodity is both the performer and the performance of the naturalization of history, no less than the historicization of nature. In other words, the commodity is the staging of 'second nature' its unmaking no less than its making." Taussig, Mimesis, 233.

(c) 2019 Milan Kroulík

https://www.kritike.org/journal/issue 24/kroulik june2019.pdf

ISSN 1908-7330

(c) BY-NC-ND 
objecthood under capitalism, demystifying and reenchanting, out-fetishizing the fetish." 42 In a society employing the category of art, an artwork is produced. But it is also produced by the things themselves. One cannot make a painting out of anything, one does it together with things, even if cultural consensus tries to suppress the consciousness of such activity. In societies, where there was or is no concept of art, there are, nonetheless, works that can be classified (by us) as art-artworks. Since things have lives of their own, they sometimes give themselves to humans, and sometimes not. Common classification, however, is based on a logical slip that obfuscates that a (seemingly) eternal quality is retroactively projected onto objects. Common knowledge appears to be unaware of the cognitive process, which is what makes false consciousness of idealism possible. ${ }^{43}$

Such idealization of art, which is accompanied by a nigh mystical conceptualization of both artists and intelligent people as the 'genius,' is then projected onto whatever is deemed fitting. What is and what is not art thus changes and so does the new production of art. The similarities that are possible to be perceived change. And things need not show themselves in all their forms to sensual apprehension. But when they do talk back, they can jumble one's habitual existence. ${ }^{44}$ The category of art is produced as much by humans, as it is by things. And it acts upon them, it, too, is productive. But it is productive in historically-bound situations. Things, artworks can persist in their existence beyond the confines of the historical situation within which they have come to be. And they can tell things to other beings. Yet, since sense is produced historically, things will not necessarily say the same things to different people. What things say depend on their juxtaposition with other things. After all, production is always accompanied by "unintentional elements". ${ }^{45}$ It is here, for Walter Benjamin, that truth (as historically contingent) may appear, what he calls "profane illumination." 46 This, here, is

42 Ibid., 1.

${ }^{43}$ Incidentally, this is exactly what the Buddha allegedly taught. In academic Buddhist translations idealism is named eternalism. That operation, which misapprehends the real fact of transitory existence and proceeds to think the world from this misapprehension. The other pole that the Buddhist Middle Way criticizes is the one called nihilism, or in more philosophical Western terminology that of naive, because static, positivism, the one Marx so amusingly pokes fun at. The difference between certain Buddhisms and certain Marxisms lies in their differing soteriological goals - one aims to extinguish existence in the phenomenal world, the other aims to restructure the phenomenal world into an ideal world-communism. Techniques of meditation (e.g., asubha kammatthhāna, i.e., meditation on corpses) also proceed dialectically to make the transitory constructedness of the phenomenal world apparent. Cf. Klima, "The Telegraphic Abject," 553-554, 561-564.

${ }^{44}$ E.g., Taussig, Mimesis, $226 \mathrm{ff}$.

${ }^{45}$ Buck-Morss, Origin, 125-126.

${ }^{46}$ Ibid.

(c) 2019 Milan Kroulík

https://www.kritike.org/journal/issue 24/kroulik june2019.pdf

ISSN 1908-7330 
the interaction, in the (conscious) co-production of sense on the intersection of material and ideational processes.

Our times may be such that the "individual finds the abstract form ready made," 47 but they are (quite apparently, otherwise I would not be writing these words) not times, where there is nothing but encounters between ahistorical subjects and abstract forms. It is precisely because even the idealist, capitalist cultural formation necessarily draws on the mimetic faculty that this cosmological formation is neither ontologically static, nor pure. It may well be that capitalism is most sophisticated in suppressing very real historical changes into a seemingly eternal nature, but that does not make it eternal and unchanging. Indeed, some demonstrate that it changes so fast, that its change is barely perceptible. ${ }^{48}$ And so do people. But things live on, and can speak back, unsettle our certainties. What is difficult is to unearth what was thrown away. ${ }^{49}$ And while I am not sure about how common "profane illumination" might be, it is important to remember that what humans can do, is modify production processes. And the category of art (much like the category of education), because it produces realms outside the capitalist production process, opens spaces for experimentation.

\section{VIII.}

Art is everywhere and nowhere. Anything is and is not an artwork. There is artwork-becoming. Anything can become a source for conscious production of works of art. Things, concepts, humans, faculties are histories. Reality emerges from within interactions of histories. Reality is becomingreal, and it is specific to each one of us. It is montage, the combination of different images, forms that create new meaning by way of similarity and difference. The forms through which we create our realities are shared. They are webs of similarities in which things, concepts, humans and faculties emerge and which in turn produce further similarities and differences. Things that might have, at one time, appeared to certain humans as apparently similar, might begin to appear radically different. While such similarities and differences are apprehended cognitively, they are reproduced in physical actions and more stable physical creations such as things. But production always has its "unintentional" components. What

\footnotetext{
${ }^{47}$ Ibid., 45.

48 Taussig, following Benjamin, calls this the 'recently outmoded,' that is all the commodities, styles, behaviors of yesteryear that seem strange today. Cf. Taussig, Mimesis, 230 ff.

${ }^{49}$ Which appears to be easier at the margins of capitalism. Cf. Ibid. 
seems given now must not appear so in the future..$^{50}$ Mimesis is, thus, becoming-similar not becoming-similar-to. Any perception and creation draw on the mimetic faculty. And that in turn is fickle-that what is needed to create copies is also that which collapses clear distinctions between the original and the copy. For the copy draws on the power of the original. It becomes powerful in its own right. ${ }^{51}$ Representation is always creation. And it is the ground that makes possible for "life to produce art" and "art to become life". The two processes are inseparable. It is a "two-way street operating between nature and history." 52

When Aristotle wrote that "objects which in themselves we view with pain, we delight to contemplate when reproduced with minute fidelity: such as the forms of the most ignoble animals and of dead bodies," 53 he used the mimetic faculty to perceive similarities and differences, but it played a trick on him. In distinguishing object and copy, he did not really distinguish it: "Thus the reason why men enjoy seeing a likeness is, that in contemplating it they find themselves learning or inferring, and saying perhaps, 'Ah, that is he.' " 54 Of course, the copy is both, it "is and is not he". That is the power it draws from the original. But the original itself is viewed through the copy, just like how montage modifies the meaning of the preceding image through the other image. ${ }^{55}$ Sentient beings and things are as much reality as representation. And a concrete effect is never ensured. This is perhaps best demonstrated on the example of katharsis. Many viewers present at a dramatic performance might indeed experience katharsis (mediated by mimesis) others will not. Because, it must first be learned to perceive a dramatic performance in such a way that katharsis can ensure. One must acquire the intellecto-perceptual formation that enables the sensual perception of a drama as a whole; one must become similar to the dramatic performance as a whole, to be able to experience katharsis. This, too, is montage, of a specific idea of a whole, as well as various material circumstances. Aristotle imagines

50 "But not until Benjamin and Adorno articulated the problem within the frame of a Marxist theory of society did they name the source of the 'unintentional' elements: the socioeconomic structure mediated all geistige production and hence expressed itself within cultural artifacts - alongside (and often in contradiction to) the subjective intention of their creators." Buck-Morss, Origin, 79.

51 This is the reason for Plato's uneasy relationship with representation.

52 Taussig, Mimesis, 250.

${ }^{53}$ Aristotle, Poetics, IV.

${ }^{54}$ Ibid. Nonetheless, I wonder: do or did 'men' really say that? It appears to me that it was Aristotle here who left empirical inquiry for speculation. Who proceeded from the general to the particular and not the other way around? Otherwise he need not have speculated about what men and women say, he could have just asked them.

55 "Especially pertinent was the way Eisenstein came to understand within and as a result of those principles the interdependence of montage with physiognomic aspects of visual worlds." Taussig, Mimesis, 28.

(C) 2019 Milan Kroulík

https://www.kritike.org/journal/issue 24/kroulik june2019.pdf

ISSN 1908-7330 
(dramatic) totality as preexisting physical performance and apprehension, when, in fact, any whole is a project in the making. ${ }^{56}$ The conceptual slip between an artwork having an effect and an artwork having a determinate effect is typical of idealist cosmology. However, there are many ways of perceiving (being affected by) a dramatic performance, many sources of pleasure. And it is only when thinking from the particular to the general that such new practices open up. It is a letting go of the acquired ideational form 'totality.'

\section{IX.}

Today, artists and art exist, intertwined as ideational concept and physical reality. A mimesis of ideational and material imitation qua creation. What one can do, is to consciously modify the mimetic process (and thus its externalized results), while accepting its indeterminacy. Taussig calls this "mastery of non-mastery." As Benjamin "argued that the truth of the novel did not depend on the interpreter's ability to empathetically identify with the sentiments expressed in the novel or with the author's intent instead, truth lay within the novel itself. This truth was not immune to history, and perception of it was in fact enhanced by the temporal distance separating the interpreter from his object." 57 Creating variations of forms (on any level of reality) that then create reality is what reality is. But forms are always already content and society is based on "essentially inarticulable and imageric, nondiscursive knowing of social relationality." 58 Sensorial (re)production is a becoming of the unconscious ground from which societies emerge. And artistic creations bear on this ground more than ideational, non-material ones. What is at stake are the material histories that have been suppressed by capitalist imagery. But it is not enough to create forms, images that are beyond capitalist convention. Not all contexts enable variations of forms and imagery that might open up real possibilities for a really-made up beyond this idealism. Without awareness that "purity" is impossible, this system will continue being recreated. There is no purely non-capitalist realm at this historical moment, and acting as if there were one, instantaneously means continuing in the very system one wants to overcome. It means that the dance of mimesis that makes such acting possible will continue to be repressed. And nature will appear as Nature, culture as Culture, history as History. And the latter will be imagined to change only through breaks, even as it keeps on changing all the time. Humans will think that there are essential differences between humans themselves, and between humans and non-humans. All

\footnotetext{
${ }^{56}$ Lacoue-Labarthe, Histoire, 139.

${ }^{57}$ Buck-Morss, Origin, 79.

${ }^{58}$ Michael Taussig, “History as Sorcery," Representations, 7 (1984), 87.
} 
while continuing to become similar to others-but unconsciously. Humans will be prisoners of the reality they co-create. That is what some in this society profit from. Because of this, the notion of art is important, not because it is better than any other category, but because it creates a space for experimental creation of critical forms. (Critical) forms are not only artworks in the common sense; everyday practice is as much art as theater. But through art, it is easier to find things to which one can become similar that work outside the dominant system - or have been left behind. That way, the elements from which the future as history will be montaged can be modified. And the more forms are created, the more all might change differently than a dominant system expects. This is "mimetic excess." 59 Creating an abundance of forms that make the mimetic faculty apparent-making apparent existence as both objective and subjective at the same time, by heeding the little things, the particularities, that which tends to be ignored, even oppressed by those that think themselves grand, above others. And through that, to make not Art, but artworks and thus history:

As the nature that culture uses to create second nature, mimesis chaotically jostles for elbow room in this force field of necessary contradiction and illusion, providing the glimpse of the opportunity to dismantle that second nature and reconstruct other worlds-so long as we reach a critical level of understanding of the play of primitivism within the mimetic faculty itself. This is why I cite Benjamin's likening of thinking to the setting of sails in the winds of world history-let us emphasize the worldliness of this history-in which the sails as images (read mimesis) develop into concepts according to how they are set. Here is the space for human agency and shrewdness, the setting of the sail within the bufetting of history. ${ }^{60}$

Department of Religious Studies, Charles University, Prague, Czech Republic and Department of Philosophy, Université Toulouse - Jean Jaurès, Toulouse, France

\section{References}

Adorno, Theodor, Negative Dialectics, trans. by E.B. Ashton (London and New York: Routledge, 1973).

Aristotle, Poetics, trans. by S. H. Butcher (London: MacMillan \& Co., 1902). Benjamin, Walter, "On the Mimetic Faculty," trans. by Edmund Jephcott, in Selected Writings: Volume 2, Part 2, 1931-1934, ed. by Michael W. Jennings, Howard Eiland, and Gary Smith (Cambridge, MA and London England: The Belknap Press of Harvard University Press).

59 Taussig, Mimesis, $254 \mathrm{ff}$.

60 Ibid., 71 (author's emphasis).

(C) 2019 Milan Kroulík

https://www.kritike.org/journal/issue 24/kroulik june2019.pdf

ISSN 1908-7330 
"The Work of Art in the Age of Its Technological Reproducibility," trans. by Edmund Jephcott, in Selected Writings: Volume 3, 1935-1938, ed. by Howard Eiland and Michael Jennings (Cambridge, MA and London, Englad).

Buck-Morss, Susan, The Dialectics of Seeing: Walter Benjamin and the Arcades Project (Cambridge, MA: MIT Press, 1989).

The Origin of Negative Dialectics: Theodor W. Adorno, Walter Benjamin and the Frankfurt Institute, (London and New York: Collier Macmillan, 1977).

Derrida, Jacques, Of Grammatology, trans. by G.C. Spivak (Maryland: The Johns Hopkins University Press, 1976).

Halliwell, Stephen, The Aesthetics of Mimesis: Ancient Texts and Modern Problems, (Princeton: Princeton University Press, 2002).

Klima, Alan, "The Telegraphic Abject - Buddhist Meditation and the Redemption of Mechanical Reproduction," Comparative Studies in Society and History, 43:3 (2001).

Kramer, Fritz W., The Red Fez: Art and Spirit Possession in Africa, trans. by M. Green, (London/New York: Verso, 1993).

Krämer, Sybille and Horst Bredekamp, "Kultur, Technik, Kulturtechnik Wider die Diskursivierung der Kultur," in Bild, Schrift, Zahl, ed. by Sybille Krämer and Horst Bredekamp (München: Wilhelm Fink Verlag, 2009).

Lacoue-Labarthe, Phillipe, Poétique de l'histoire (Paris: Galilée, 2002).

Marx, Karl and Friedrich Engels, The German Ideology including Theses on Feuerbach and Introduction to the Critique of Political Economy, trans. by C. Dutt, W. Lough, and C.P. Magill (New York: Prometheus Books, 1998).

Mitchell, W. J. T., “There Are No Visual Media," Journal of Visual Culture, 4:2 (2005)

Rousseau, Jean-Jacques, Politics and the Arts: Letter to M. d'Alembert on the Theatre, trans. by A. Bloom (Ithaca: Cornell University Press, 1960).

Taussig, Michael, "History as Sorcery," Representations, 7 (1984). Mimesis and Alterity: A Particular History of the Senses (New York: Routledge, 1993). 